\section{Skewed maturation of virus-specific CTLS?}

\author{
Laila E. Gamadia ${ }^{1,2}$, In EKe J. M.ten Berge ${ }^{1}$, Louis J. \\ Picker ${ }^{3}$ and Renéa.W.van Lier ${ }^{2}$ \\ 'Department of Internal M edicine, RenalTransplant Unit and \\ ${ }^{2}$ Department of Experimental Immunology,Academic M edical Center, \\ Amsterdam, The N etherlands. ${ }^{3} V a c c i n e$ and GeneTherapy Institute, \\ Oregon Health Science University, Beaverton, OR 97006, USA. \\ (r.vanlier@ amc.uva.nl)
}

Persistence of HIV-1 and onset of AIDS are reportedly due to the skewed maturation of cytotoxic T lymphocytes (CTLs), which fail to acquire an effector phenotype and coherent cytotoxic capability ${ }^{1,2}$. However, these allegedly nonfunctional $\mathrm{CD} 8^{+} \mathrm{T}$ cells may be predominant in distinct phases of protective immune reactions against other viruses, cytomegalovirus (CMV) for example. We argue that skewed maturation of CTLs may be a consequence rather than cause of viral persistence.

Virus-specific $\mathrm{CD} 8^{+} \mathrm{T}$ cell maturation can be accurately dissected using a combination of phenotypic markers such as CCR7, CD27, CD45RA and/or CD45RO ${ }^{3,4}$. Combinations of these markers define naïve $\mathrm{T}$ cells

$\left(\mathrm{CD} 45 \mathrm{RA}^{+} \mathrm{CD} 27^{+} \mathrm{CCR} 7^{+}\right)$, central memory

cells $\left(\mathrm{CD} 45 \mathrm{R} 0{ }^{+} \mathrm{CD} 27^{+} \mathrm{CCR} 7^{+}\right)$, effector-memory cells (CD45R $\left.0^{+} \mathrm{CD} 27^{+/} \mathrm{CCR} 7^{-}\right)$and terminally differentiated effector $\mathrm{T}$ cells

(CD45RA ${ }^{+} \mathrm{CD} 27^{-} \mathrm{CCR}^{-}$). Many pathological viral disease states have been attributed to impaired CTL effector function ${ }^{5}$; in these states, cells do not differentiate into an effector phenotype and fail to produce IFN- $\gamma$ or contain cytotoxic effector molecules such as perforin and granzyme B. It has been argued ${ }^{1}$ that maturation of HIV-specific $\mathrm{CD} 8^{+} \mathrm{T}$ cells is skewed in asymptomatic HIV-infected individuals because the CTLs are mainly
CD45RA-CCR7-, whereas

CMV-specific CTLs, for

example, are terminally differentiated and mainly

CD45RA ${ }^{+}$CCR7 ${ }^{-}$. The authors suggest ${ }^{1}$ that a maturational impairment of HIV-specific $\mathrm{CD}^{+} \mathrm{T}$ cells exists in these asymptomatic HIV carriers. In healthy CMV-seropositive individuals, CMV-specific $\mathrm{CD}^{+} \mathrm{T}$ cells are also predominantly of the CD45RA-CCR7 phenotype ${ }^{6}$, but are able to control CMV infection.

Skewed maturation of virus-specific $\mathrm{CD} 8^{+}$ $\mathrm{T}$ cells may, therefore, not be virus-specific, but could be related to antigen-exposure and clinical conditions. In primary CMV and Epstein-Barr virus infections, where antigen is abundantly present, virus-specific $\mathrm{CD} 8^{+} \mathrm{T}$ cells in the peripheral blood show a proliferating memory phenotype: they are

$\mathrm{CD}^{2} 5 \mathrm{RA}^{-} \mathrm{CCR} 7^{-} \mathrm{CD} 27^{+}\left(\mathrm{ki}-67^{+}\right)^{7}$ and produce cytotoxic molecules. Once the virus is cleared, CD45RA ${ }^{+} \mathrm{CD} 27^{-} \mathrm{CD}^{+} \mathrm{T}$ cells emerge in the peripheral blood. Alterations to $\mathrm{CD}^{+}$subsets in the periphery may reflect a redistribution effect rather than a maturation effect: the effector cells reemerge into the circulation from the infected tissues, where some will remain as memory cells. The CD45RA ${ }^{-} \mathrm{CCR} 7^{-} \mathrm{CD} 27^{+}$phenotype described in HIV infection may be caused, therefore, by the migration of HIV-specific CTLs to sites of viral replication. It is not a cause of disease, but rather a consequence of disease. The high $\mathrm{CD}^{+} \mathrm{T}$ cell turnover and the general activation status of the immune system in HIV infection leads to a constant ongoing recruitment of cells into the HIV-specific pool $^{8}$. Thus, analysis of these cells in the peripheral blood only shows the proliferating $\mathrm{CD} 27^{+} \mathrm{CD} 45 \mathrm{RA}^{-} \mathrm{CD} 45 \mathrm{R}^{+}$subset of HIV-specific $\mathrm{CD} 8^{+} \mathrm{T}$ cells, which have low perforin content compared to CD27- effector cells ${ }^{2}$.
The heterogeneous phenotype of virusspecific cells in healthy individuals renders the status of $\mathrm{T}$ cell subset differentiation of very little value for predicting viral disease outcome in humans. This is especially the case because access to these cells is mainly via the peripheral blood, and individual genetic differences in the host and pathogen can also play a role. Clinical symptoms and quantification of viral load, therefore, still appear to be the best parameters with which to monitor viral disease in a clinical setting. However, dysfunctional CTLs were expanded in melanoma patients 9 . This suggests that T cell subset phenotyping is important during the follow-up of immunotherapy, especially for vaccines that are designed to induce potent cytotoxic responses, such as current HIV and anti-tumor vaccines.

Subset analysis has, therefore, provided further insights into how effective immune responses are established. However, the data obtained so far under human pathological conditions cannot predict the outcome of disease because these data are mainly assessed in peripheral blood, a compartment in which the antigen-specific cells are in transit to their target site and will not yet display their complete functional state. Because many aspects of antigenic cellular immune responses are unresolved, it is still too early to be able to ascribe disease states to dysfunctional CTL responses. Many other factors appear to influence the outcome of disease and presently little is known of the functional status of CTLs at sites of infection.

\footnotetext{
C Champagne, P. et al. Nature 410, 106-111 (2001) A ppay.V. et al. J. Exp. M ed. 192,63-75 (2000). Sallusto, F. et al. Nature 401, 708-712 (1999).

Hamann, D. et al. J. Exp. Med. 186, 1407-1418 (1997).

Welsh, R. M. J. Exp. Med. 193, 19-22 (2001).

Gamadia, L. E. et al. Blood 98, 754-761 (2001).

Roos, M.T. et al. J. Infect. Dis. 182, 451-458 (2000).

8. Hazenberg, M. D. et al. Nature M ed. 6, 1036-1042 (2000)

9. Lee, P. P. et al. Nature M ed. 5, 677-685 (1999).
} 